\title{
Global Citizenship Education; A Framework of Civic Literacy in Indonesia
}

\author{
Siti Maizul Habibah ${ }^{1, *}$ Sapriyah $^{2}$
}

\author{
${ }^{1}$ Universitas Pendidikan Indonesia \\ ${ }^{2}$ Universitas Pendidikan Indonesia \\ *Corresponding author.Email: sitimaizulhabibah@upi.edu
}

\begin{abstract}
The purpose of this paper is to describe why there is a need for global citizenship education and also to describe global citizenship education on civic literacy in any aspect. The method used in writing this scientific article is descriptive qualitative and literature review data collection which produces the idea of global citizenship education as a framework of civic literacy in Indonesia. The results show that global citizenship education is necessary because education involves active participation of world citizens in projects related to global social, political, economic, and environmental issues to be responsible, instill the basis of sustainable development for human welfare and environmental preservation and this global citizenship education frames literacy. civic on the aspects of civic skills, civic knowledge and civic dispositions because in global citizenship education the expected demands are that the citizens of the world can think, share and act for the continuity of a harmonious world continuously and develop a more tolerant attitude.
\end{abstract}

Keywords: Awareness, Global Citizenship Education, A Framework, Civic Literacy

\section{INTRODUCTION}

Global citizenship education is a type of citizenship science that involves the active participation of students in projects related to global social, political, economic and environmental issues. The two main elements of GCE are global awareness, namely the moral and ethical aspects of global issues, and global competence, which are skills that enable students to compete in the global job market. GCE is the idea of government and NGOs to deal with the emergence of supranational institutions, regional economic blocs, and the development of information and communication technology. All of these factors encourage a more global and collaborative approach to education.

Global citizenship consists of voluntary practices oriented towards human rights, social justice, and the environment at the local, regional and global levels.[1] Unlike national citizenship, global citizenship does not imply any official status or allegiance to the government.[2] The emergence of regional economic blocs, supranational political institutions such as the European Union, and advances in ICT have encouraged many countries to prepare for the competitiveness of their people in the global job market. Global citizenship education (GCE) programs are being introduced at the primary, secondary and tertiary levels, as well as independent non-governmental organizations, grassroots organizations, and other large-scale educational organizations such as the International Baccalaureate (IB) and UNESCO.[3]

The purpose of this paper is to describe why there is a need for global citizenship education and also to describe global citizenship education on civic literacy in any aspect.

\section{METHODS}

The research method used in this research is descriptive qualitative. Descriptive research method is defined as a problem-solving procedure investigated by describing or describing the state of both the subject and the object of research. While data collection uses a literature review, this is used in this study where researchers use secondary data in the form of documents derived from books, through various print and electronic media, websites or blogs, or other sources. These documents help researchers to reconstruct all events and turn them into supporting data to explain in more detail the real conditions of society or the community environment with the intent and purpose of finding facts (fact-finding), which then leads to identification (problem-identification) and in the end leading to problem solving. 


\section{RESULTS AND DISCUSSION}

\subsection{The Urgency of Global Citizenship Education}

Information and communication technology so that the connection from one individual to another becomes very easy even though the distance is far in the world wherever the country is located. Likewise with the facts that the number of individual internet users in the world rose $16 \%$ in 2005 to $39 \%$ in 2013. Likewise, users in Africa from $2 \%$ to $16 \%$. Another reason is about the journey of people on airplanes across countries, 3.1 billion in 2013 and will be 6.4 billion in 2030 . Likewise, the increase in the value of Exports that adorn the faceof the business world shows that this technology embodies a very deep connectedness.

Likewise, this phenomenon was followed by an increase in world tension over conflicts that occur everywhere. In 2012 there were many incidents recorded that 45.2 million people left their homes due to conflicts, persecution and violence that occurred in the world. In 2000 many of the world's poor died 310,000 people and were seriously injured in various parts of the world. In 1995, it was recorded that as many as . of children were killed.

Another fact that is also a threat to humans on earth is Global Emissions where the increase in carbon dioxide levels by $46 \%$ since 1990 is very dangerous because this is the cause of global warming. From 2005 to 2010 the forests in Africa and South America also shrunk, by about 3 million hectares per year. The problem is also the increasing number of people living with HIV in the world.

By looking at the facts and issues that are developing and can become a threat to humans on earth and the environment we live in, there needs to be a thought to save the earth with its sustainability so that there is no extinction. For that we need a policy and an education system to save the life of this earth.

Education is not only about academic knowledge, but also teaches and explores all human potential and how to live side by side in harmony[4]. Lessons are directed to cognitive knowledge schemes such as: core values of life, attitudes and behavior, human rights, gender equality, diversity and the continuity of a harmonious environment. The target of education, both formal and informal, must be able to reach all levels of the world's community.
For that we need global or world citizenship education. Where this education promotes and supports peace, with an emphasis on belonging to this world is very high. If this happens it will bind people to take more constructive action and find solutions globally through constructive change. This education will certainly encourage sustainable development with full responsibility.

So this global citizenship education will be a system that is built in transformation, in the fields of: Human Rights, Democracy, Tolerance and Sustainable Development[5]. In developing global citizenship education, it is certain to have big challenges. This system requires the same conditions regarding values or values in any system such as social, economic, political, cultural and religious.

Education should be encouraged to be sensitive and quickly analyze actual issues and be ready to be anticipated and resolved before other problems arise. All teachers should teach appropriately and promote education about global citizenship. Nurturing and maintaining the ethos of global citizenship[6].

This is the reason behind the importance of Unesco to promote global citizenship education. Unesco should recruit many professionals and experts in spreading about this issue. The following system must be implemented: Work to mainstream Global Citizenship Education, Promote Transformative Teaching and Support a Network of Stakeholders to renew interest and reconstruct objective.

Studying citizenship education is also in line with the results of the conference of nine education ministers from the most populous countries in the world including Indonesia in New Delhi, India in 1996 which agreed that education is preparing individuals as responsiblecitizens and members of society, instilling the basis of sustainable development for human welfare and preservation of the environment as well as providing education that is oriented towards mastering the development and dissemination of science and technology and the arts for the benefit of humanity[7].

Citizenship education is universal and comprehensive which is not only studied in Indonesiabut also in other countries in the world, not only in the context of school civics but also community civics. preparation of citizens as part of the citizens of the world [8]. 


\subsection{Global Citizenship Education as a FrameworkLiteracy Civic}

In the repertoire of civics knowledge, civic literacy is placed as a basic element of political virtue of citizenship, in which civic literacy implies mastery of the forms of political knowledge of citizens in particular and will be manifested in civic activities. Civic literacy has several components that become an achievement, including civic skills, civic knowledge and civic dispositions (citizenship attitudes) all of which aim to make good citizens. Before entering into civic literacy, of course, the thing that must be improved or improved is the quality of literacy or the level of reading in the community.

Citizens should know about their rights and obligations as citizens, the laws, values, and norms that apply to the conditions of life in society, nation and stateso that the values contained in them can be constructed in daily behavior in order to become good citizens. Therefore, it is necessary to have an insight into citizenship itself, namely the existence of civic literacy. Becomes a demand along with a lack of insight It becomes a demand along with the lack of national insight in order to make good citizens in the face of globalization. Civic literacy is a knowledge and ability of citizens in overcoming social, political and state problems [4]. In the repertoire of civics, civic literacy occupies a basic point in carrying out political actions of its citizens.

The idea expressed can be understood that, in civic literacy, it is also aimed at mastering political insight which ultimately manifests in the behavior of the nation and state[4]. Civic literacy is also interpreted as a knowledge capacity and the ability of citizens to understand their political activities, or more broadly defined as a knowledge capacity on how to activelyparticipate and initiate change in the larger community and society[9].In principle, civic literacy is expertise in terms of mastering the scope of civic education. Citizenship education has a strategic role in building the global insight of citizens.

Citizenship education is not always stagnant in the discussion of learning rights and obligations as citizens, but is more universal in an effort to prepare citizens to become global citizens. The same idea is that the existence of civic education is for the provision of global knowledge[10]. There are three core components in the discussion of civic literacy, namely civic knowledge, civic skills, and civic dispositions. Citizenship knowledge (civic knowledge) is an insight into how to live in the nation and state in the state aspect by reducing the values of Pancasila, citizenship skills (civic skills) are expertise in developing a talent or skill to take part in advancing the country, and the last is attitude Citizenship (civic dispositions) is an attitude that must be clear in positioning itself as a citizen, of course, in carrying out obligations as a citizen. Thiscomponent is an important factor in the effort to become a good citizen. The success of developing integrative behavior in citizens can develop a productive national and state life to realize the common good as desired in national ideals and state goals. These three components can be included in civic skills, which become an intellectual skill that prioritizes the formation of citizens who are broad-minded, effective and responsible, among others, are skilled in critical thinking. Critical thinking skills include how a person identifies, describes, describes, explains, analyzes, evaluates, determines and defends opinions regarding public issues.

For that we as individuals who care about the life of a peaceful and harmonious world must do: think, which is to learn about global issues that arise and think what you can do, Share, which is to spread your knowledge and brilliant ideas to anyone so that the world will be better and ask for help. the people you share to share with others as well and Act That is to change our ways and behavior to make the world full of peace, sustainable world harmony and develop a more tolerant attitude. All of these are aspects of stages that are continuous with aspects of Civic literacy, which have several components that become achievements, including civic skills, civic knowledge and civic dispositions.

\section{CONCLUSION}

Global citizenship education is necessary becauseeducation involves the active participation of world citizens in projects related to global social, political, economic and environmental issues to be responsible, instill the basis of sustainable development for human welfare and environmental preservation and this global citizenship education frames civic literacy in aspects civic skills, civic knowledge and civic dispositions because in global civic education it is expected that citizens of the world can think, share and act for the sustainability of a harmonious world continuously and develop a more tolerant attitude.

\section{ACKNOWLEDGMENTS}

I would like to thank all parties involved in this research, Universitas pendidikan Indonesia and 
also Universitas Negeri Surabaya.

\section{REFERENCES}

[1] T. A. Catalano, "Occupy: A case illustration of social movements in global citizenship education," Educ. Citizsh. Soc. Justice, vol. 8, no. 3, 2013.

[2] C. A. Torres and E. Bosio, "Global citizenship education at the crossroads: Globalization, global commons, common good, and critical consciousness," Prospects, vol. 48, no. 3-4, 2020.

[3] J. Arthur, "The longings and limits of global citizenship education: the moral pedagogy of schooling in a cosmopolitan age . By Jeffrey S. Dil ,"Br. J. Educ. Stud., vol. 62, no. 1, 2014.

[4] R. A. Saputri, Triyanto, and Winarno, "Using critical multiliteracy learning in developing students' civic literacy in the industrial era 4.0 education," in AIP Conference Proceedings, 2019, vol. 2194.

[5] "Global citizenship education.” .

[6] I. Davies, M. Evans, and A. Reid, "Globalising citizenship education? A critique of 'global education' and 'citizenship education,", Br. J. Educ. Stud., vol. 53, no. 1, 2005.

[7] J. P. Myers, "Rethinking the social studies curriculum in the context of globalization: Education for global citizenship in the U.S," Theory Res. Soc. Educ., vol. 34, no. 3, 2006.

[8] Audry Osler, "Citizenship Education and the Ajegbo report: re-imagining a cosmopolitan nation," London Rev. Educ., vol. 6, no. 1, pp. 11-25, 2008.

[9] A. Dwipayana, "Pengelolaan Sistem Pendidikan Dan Pelatihan Di Badan Pendidikan Dan Pelatihan Daerah Provinsi Jawa Barat," Repos. Univ. Pendidik. Indones., no. 0900151, 2013.

[10] A. Rinenggo and M. Murdiono, "Utilization of Schoology for the Development of PPKn Teaching Materials Based on E-learning," 2020. 